\title{
Effectiveness of a rapid soil incubation method for determining potential acidity of soils in Rio Grande do Sul, Brazil
}

\section{Gustavo Brunetto ${ }^{1}$ Rodrigo Otávio Schneider Souza ${ }^{1}$ Rogério Piccin $^{2}$ Roque Junior Sartori Bellinaso ${ }^{1}$ João Kaminski ${ }^{1}$ Carlos Alberto Ceretta ${ }^{1}$ Lincon Stefanello ${ }^{2 *}$ (iD) Rodrigo Krammes ${ }^{1}$ Jacson Hindersmann ${ }^{1}$ Luciano Colpo Gatiboni ${ }^{3}$}

${ }^{1}$ Departamento de Solos, Universidade Federal de Santa Maria (UFSM), Santa Maria, RS, Brasil.

${ }^{2}$ Programa de Pós-graduação em Ciência do Solo, Centro de Ciências Rurais (CCR), Universidade Federal de Santa Maria (UFSM), 97105-900, Santa Maria, RS, Brasil. E-mail: linconfa@hotmail.com. "Corresponding author.

${ }^{3}$ Departamento de Solos e Recursos Naturais do Centro de Ciências Agroveterinárias (CAV), Universidade do Estado de Santa Catarina (UDESC), Lages, SC, Brasil.

\begin{abstract}
Potential soil acidity can be measured by two methods in the states of Rio Grande do Sul (RS) and Santa Catarina (SC): solution SMP or solution TSM (Buffer Santa Maria). Calibration of these methods is done by incubating soils for long periods (180 days) of CaCO. The hypothesis of this study is that it is possible to reduce the incubation period in soils by using a soluble base such as calcium hydroxide. The study aimed to estimate potential acidity in a group of soils by moist incubation with $\mathrm{Ca}(\mathrm{OH})_{2}$ (short) as an alternative to the typical method with $\mathrm{CaCO}_{3}$ (long) and relate to the values estimated by the equation used by the Soil Chemistry and Fertility Commission of Rio Grande do Sul and Santa Catarina (CQFS-RS/SC; 2016). Ten soils with sandy texture and low organic matter content were collected at 0-20cm in the Campanha Gaúcha region of the state of $R S$ and incubated for 180 days with doses of CaCO, equivalent to 0, 25, 50, 75, 100, 125 and 150\% of the lime requirement estimated by the solution TSM to raise to pH 6.0. Soils were also incubated for 4 days in an oven at $35^{\circ} \mathrm{C}$ with $0.22 \mathrm{~mol} \mathrm{~L}^{-1}$ $\mathrm{Ca}(\mathrm{OH})$, at doses equivalent to $\mathrm{CaCO}_{3}$. Short incubation of the soil with $\mathrm{Ca}(\mathrm{OH})$, may substitute long incubation with $\mathrm{CaCO}$, Also, estimating potential acidity using the equation of the CQFS-RS/SC (2016) overestimated potential acidity in soils with solution TSM pH values lower than 6.0 in this study.
\end{abstract}

Key words: sandy soils, lime dose, short incubation, long incubation.

Eficácia de um método rápido de incubação de solo na determinação da acidez potencial em solos no Rio Grande do Sul, Brasil

RESUMO: A acidez potencial do solo pode ser medida por dois métodos nos estados do Rio Grande do Sul (RS) e Santa Catarina (SC): indice SMP ou solução TSM (Tampão Santa Maria). A calibração destes métodos é feita pela incubação de solos por longos periodos (180 dias) com quantidades crescentes de $\mathrm{CaCO}_{3}$. A hipótese deste estudo é que é possivel reduzir o período de incubação em solos usando uma base solúvel como o hidróxido de cálcio. O trabalho objetivou estimar a acidez potencial em um grupo de solos por meio de incubação úmida com $\mathrm{Ca}(\mathrm{OH})_{2}$ (curta) como alternativa ao método típico com $\mathrm{CaCO}_{3}$ (longa) e relacionar com os valores estimados pela equação utilizada pela CQFS-RS/SC (2016). Dez solos com textura arenosa e baixo conteúdo de matéria orgânica foram coletados a 0-20cm na região da Campanha Gaúcha e incubados por 180 dias com doses de CaCO3 equivalentes a 0, 25, 50, 75, 100, 125 e 150\% da exigência de calcário estimada pela solução TSM para elevar o pH a 6,0 (longa). Os solos foram também incubados por 4 dias em estufa a $35^{\circ} \mathrm{C} \mathrm{com} 0,22 \mathrm{~mol} \mathrm{~L}^{-1}$ de $\mathrm{Ca}(\mathrm{OH})$, em doses equivalentes ao $\mathrm{CaCO}_{3}$ (curta). A incubação curta do solo com $\mathrm{Ca}(\mathrm{OH}) 2$ pode substituir a incubação longa com CaCO, Além disso, a estimativa da acidez potencial utilizando a equação do CQFS-RS/SC (2016) superestimou a acidez potencial de solos com valores de pH em solução TSM inferiores a 6,0 neste estudo.

Palavras-chave: solos arenosos, dose de calcário, incubação curta, incubação longa.

The solution TSM has been used to replace of the SMP solution in the states of Rio Grande do Sul (RS) and Santa Catarina (SC), because it produces similar results and does not generate wastes, which reduces the potential for contaminating laboratory workers and the environment pollution (TOLEDO et al., 2012; GAMA et al., 2013; GIULIANI, 2015). However, both methods need calibration, which uses the real potential acidity of the soil as a reference, obtained by incubating the soil with lime. Heterogeneous sets of soils are typically used in these calibrations, so that the equations represent the soil diversity of the region in which the method is used. Moreover, the calibration of the SMP solution usually requires an incubation period with lime doses up to 180 days (KAMINSKI et al., 2002), and this period may be longer in certain soils (GIULIANI, 2015). Therefore, there is a need for an alternative, and more rapid method to calibrate solution TSM, with results similar to those obtained by incubation with $\mathrm{CaCO}_{3}$. LIU et al. $(2004 ; 2005)$ propose a method of soil incubation with $\mathrm{Ca}(\mathrm{OH})_{2}$ for 86 hours, which is longer than that 
proposed by THOMPSON et al. (2010) of 48 hours. However, $\mathrm{Ca}(\mathrm{OH})_{2}$ concentration should not exceed $0.025 \mathrm{~mol} \mathrm{~L}^{-1}$, which is enough to neutralize acidity up to $9 \mathrm{cmol}_{\mathrm{c}} \mathrm{dm}^{-3}$. For this reason, the addition of solid $\mathrm{Ca}(\mathrm{OH})_{2}$ to supplement the base requirement for soils with potential acidity values greater than $9 \mathrm{cmolc} \mathrm{dm}^{-3}$ should be tested. Thus, the aim of this study was to estimate potential acidity $(\mathrm{H}+\mathrm{Al})$ in a set of soils by moist incubation with $\mathrm{Ca}(\mathrm{OH})_{2}$ (short incubation) as an alternative to the traditional method with $\mathrm{CaCO}_{3}$ (long incubation) and relate to the estimated values of $\mathrm{H}+\mathrm{Al}$ and lime requirement obtained by the equation proposed by the CQFS-RS/SC (2016).

Soil samples were collected at $0-20 \mathrm{~cm}$ of 10 soils in natural grassland areas of the Campanha Gaúcha region of RS (Table 1). Soils were air-dried, ground, passed through a $2 \mathrm{~mm}$ mesh sieve and a portion of the soil was physically and chemically characterized according to the methodology described in TEDESCO et al. (1995) (Table 1). Portions of $1.0 \mathrm{~kg}$ of soil were placed in $2 \mathrm{~L}$ polyethylene containers and incubated with $\mathrm{CaCO}_{3}$ at an average temperature of $26^{\circ} \mathrm{C}$ and relative humidity of $80 \%$. Doses consisted of $25,50,75,100,125$ and $150 \%$ of the lime requirement estimated by the SMP solution to raise $\mathrm{pH}$ to 6.0 , according to the equation proposed by TOLEDO et al. (2012). The experimental design was completely randomized with 4 replicates. Soils were kept at $60 \%$ field capacity and every two days the containers were weighed and water was replenished when necessary (GIULIANI, 2015). The soil $\mathrm{pH}$ was measured every 30 days. At 180 days of incubation, the soil was air-dried, ground, passed through a $2 \mathrm{~mm}$ mesh sieve and reserved.

For short incubation, $40 \mathrm{~g}$ portions of the 10 soils were weighed and placed into $150 \mathrm{~mL}$ Beckers.
Then, $80 \mathrm{~mL}$ of $0.022 \mathrm{~mol} \mathrm{~L}^{-1}$ calcium hydroxide solution $\mathrm{Ca}(\mathrm{OH})_{2}$ was added. In order to prepare the saturated solution of $\mathrm{Ca}(\mathrm{OH})_{2}, 15 \mathrm{~g}$ of the solid reactant with a purity of $99 \%$ was weighed and added into a 5L Becker. Afterwards, 4.5L of distilled water was added. Soon after, the solution was stirred on magnetic stirrer (Model Te-0851, Tecnal, Brazil) for two days. The solution was then left to stand for three days. Afterwards, the supernatant was transferred to another $5 \mathrm{~L}$ container and standardized to reach $0.022 \mathrm{~mol} \mathrm{~L}^{-1}$ (LIU et al., 2005). Once samples were placed into the containers, a solution of $0.022 \mathrm{~mol} \mathrm{~L}^{-1} \mathrm{Ca}(\mathrm{OH})_{2}$ was added to the replicates, according to the value of $\mathrm{H}+\mathrm{Al}$, up to a potential acidity limit of $8 \mathrm{cmol}_{\mathrm{c}} \mathrm{dm}^{-3}$. In soils with $\mathrm{H}+\mathrm{Al}$ greater than $8 \mathrm{cmol}_{\mathrm{c}} \mathrm{dm}^{-3}$, solid $\mathrm{Ca}(\mathrm{OH})_{2}$ was added in amounts corresponding to the potential acidity estimated by solution TSM to raise $\mathrm{pH}$ to 6.0 , as proposed by LIU et al.(2005). The doses were equivalent to $25,50,75,100,125$ and $150 \%$ of the lime requirement estimated by SMP solution to raise $\mathrm{pH}$ to 7.0 , according to the equation proposed by TOLEDO et al. (2012). The experimental design was completely randomized with 4 replicates. In each replicate, $1 \mathrm{~mL}$ of chloroform was added to inhibit soil biological activity, not interfering in the correction of the $\mathrm{pH}$. Shortly thereafter, the containers were covered with plastic film to reduce evaporation. Containers of soil were placed in an oven with forced air circulation at a temperature of $35^{\circ} \mathrm{C}$. The $\mathrm{pH}$ of the solution was measured at $0,24,48,72$ and 96 hours.

The values of $\mathrm{H}+\mathrm{Al}$ obtained in short incubation and by the equation of the CQFS-RS/SC $\left(\mathrm{H}+\mathrm{Al}=\mathrm{e}\left(10.665-\left(1.1483^{*} \mathrm{TSM}\right) / 10\right)\right.$ were correlated with the potential acidity obtained by the long

Table 1 - Geographic coordinates and physical and chemical characteristics of 10 soils collected in the Campanha Gaúcha region of the state of Rio Grande do Sul (RS)

\begin{tabular}{|c|c|c|c|c|c|c|c|c|c|c|c|c|c|c|}
\hline \multirow{2}{*}{ Soil } & \multicolumn{2}{|c|}{ Coordinates } & \multirow{2}{*}{$\begin{array}{c}\text { OM } \\
\%\end{array}$} & \multirow[t]{2}{*}{ Clay } & \multirow{2}{*}{$\begin{array}{l}\text { Sand } \\
\mathrm{g} \mathrm{kg}^{-1}\end{array}$} & \multirow[t]{2}{*}{ Silt } & \multirow{2}{*}{$\begin{array}{c}\mathrm{pH} \text { in } \\
\mathrm{H}_{2} \mathrm{O}\end{array}$} & \multirow{2}{*}{$\begin{array}{l}\mathrm{pH} \text { in } \\
\mathrm{TSM} \\
1: 1.5 \\
\text { ratio }\end{array}$} & $\mathrm{P}$ & \multirow{2}{*}{$\begin{array}{c}\mathrm{K} \\
\mathrm{n}^{-3}--\end{array}$} & \multirow[t]{2}{*}{$\mathrm{Ca}$} & \multirow{2}{*}{$\mathrm{Mg}$} & \multirow{2}{*}{$\begin{array}{c}\mathrm{Al} \\
\mathrm{dm}^{-3}\end{array}$} & \multirow{2}{*}{$\mathrm{H}+\mathrm{Al}$} \\
\hline & Latitude & Longitude & & & & & & & $--m g$ & & & & & \\
\hline 1 & $30^{\circ} 9^{\prime} 2.92^{\prime \prime S}$ & $55^{\circ} 13^{\prime} 20.85^{\prime \prime} \mathrm{W}$ & 1.5 & 207 & 736 & 57 & 4.7 & 5.48 & 2.8 & 96 & 1.6 & 0.8 & 0.7 & 7.9 \\
\hline 2 & $30^{\circ} 10^{\prime} 16.52^{\prime \prime S}$ & $56^{\circ} 12^{\prime} 21.02^{\prime \prime} \mathrm{W}$ & 1.2 & 157 & 757 & 86 & 4.3 & 5.32 & 9.7 & 52 & 1.8 & 0.4 & 0.9 & 9.4 \\
\hline 3 & $30^{\circ} 10.2^{\prime} 16^{\prime \prime S}$ & $55^{\circ} 12^{\prime} 16.73^{\prime \prime} \mathrm{W}$ & 1.2 & 204 & 731 & 66 & 4.6 & 5.44 & 16.2 & 80 & 3 & 0.7 & 0.5 & 8.2 \\
\hline 4 & $30^{\circ} 6 ' 56.88^{\prime \prime S}$ & $54^{\circ} 43^{\prime} 18.04^{\prime \prime} \mathrm{W}$ & 1.2 & 207 & 684 & 109 & 4.7 & 5.42 & 3.1 & 44 & 1.3 & 0.6 & 1.3 & 8.4 \\
\hline 5 & $30^{\circ} 5^{\prime} 36.48^{\prime \prime S}$ & $54^{\circ} 42^{\prime} 39.95^{\prime \prime W}$ & 1.3 & 73 & 817 & 109 & 4.4 & 5.14 & 4.8 & 44 & 1.1 & 0.4 & 1.6 & 11.7 \\
\hline 6 & $30^{\circ} 15^{\prime} 16.93 " \mathrm{~S}$ & $54^{\circ} 58^{\prime} 32.87^{\prime \prime W}$ & 1.4 & 363 & 526 & 111 & 4.4 & 4.66 & 3.4 & 116 & 2.1 & 0.9 & 2.0 & 20.3 \\
\hline 7 & $30^{\circ} 15^{\prime} 32.04^{\prime \prime S}$ & $54^{\circ} 58^{\prime} 35.21^{\prime \prime} \mathrm{W}$ & 0.9 & 58 & 885 & 58 & 5.1 & 6.11 & 4.4 & 32 & 0.9 & 0.4 & 0.2 & 3.8 \\
\hline 8 & $30^{\circ} 15^{\prime} 23.18^{\prime \prime S}$ & $54^{\circ} 58^{\prime} 41.99^{\prime \prime} \mathrm{W}$ & 1.3 & 84 & 852 & 64 & 4.9 & 5.77 & 6.2 & 56 & 1.6 & 0.5 & 0.6 & 5.7 \\
\hline 9 & $30^{\circ} 47^{\prime} 25 . " 3 \mathrm{~S}$ & $55^{\circ} 22^{\prime} 05.6^{\prime \prime} \mathrm{W}$ & 0.8 & 64 & 878 & 58 & 5.4 & 6.20 & 2.7 & 40 & 1 & 0.3 & 0.1 & 3.5 \\
\hline 10 & $30^{\circ} 48^{\prime} 41.6 ” \mathrm{~S}$ & $55^{\circ} 26^{\prime} 17.0^{\prime \prime} \mathrm{W}$ & 1.2 & 88 & 837 & 74 & 5.1 & 5.99 & 3.2 & 100 & 1.2 & 0.5 & 0.2 & 4.4 \\
\hline
\end{tabular}

$\mathrm{OM}=$ Organic matter. 
incubation of soils with $\mathrm{CaCO}_{3}$. We correlated the values of solution $\mathrm{TSM} \mathrm{pH}$ and $\mathrm{H}+\mathrm{Al}$ to the respective reference $\mathrm{pH}$ through regression analysis to obtain the mathematical model to estimate potential acidity or lime requirement to best fit the data. Results were compared statistically using confidence intervals (95\%) for the equation coefficients. To adjust the relationship between the potential acidity of the soil and the solution TSM pH values, $\mathrm{H}+\mathrm{Al}$ values were used at $\mathrm{pH} 6.0 ; 6.5$ and 7.0 for samples with $\mathrm{CaCO}_{3}$ and $\mathrm{Ca}(\mathrm{OH})_{2}$.

Organic matter contents ranged from 8.0 to $15.0 \mathrm{~g} \mathrm{~kg}^{-1}$ in the 10 soils (Table 1). Clay values ranged from 58 to $363 \mathrm{~g} \mathrm{~kg}^{-1}$. The $\mathrm{pH}$ values in water ranged from 4.3 to 5.4; in TSM from 4.6 to 6.2 ; and real $\mathrm{H}+\mathrm{Al}$ at $\mathrm{pH} 7.0$ from 3.5 to $20.3 \mathrm{cmolc} \mathrm{kg}^{-1}$, which shows a considerable variation in soil potential acidity.
The values of $\mathrm{H}+\mathrm{Al}$ estimated by the equation proposed by the CQFS-RS/SC (2016) were overestimated in relation to short incubation with $\mathrm{Ca}(\mathrm{OH})_{2}$ and long incubation with $\mathrm{CaCO}_{3}$ in any buffer range evaluated in this study (Figure 1A). The estimated $\mathrm{H}+\mathrm{Al}$ values obtained by the equations of short incubation $\left(\mathrm{H}+\mathrm{Al}=908.83 \mathrm{e}^{-0.983 \mathrm{TSM}}\right)$ and long incubation $\left(\mathrm{H}+\mathrm{Al}=454.85 \mathrm{e}^{-0.816 \mathrm{TSM}}\right)$ were lower than the values obtained by the equation proposed by the CQFS$\mathrm{RS} / \mathrm{SC}(2016)\left(\mathrm{H}+\mathrm{Al}=4283 \mathrm{e}^{-1.14 T S M}\right)$ at solution TSM $\mathrm{pH}$ values lower than 6.0 (Figure 1B). This is because the equation proposed by the CQFS-RS/SC (2016) was obtained by incubating a greater diversity of soil types, with a significant presence of soils with higher organic matter and clay contents (FOX, 1980; SSALI \& NUWAMANYA, 1982; KAMINSKI et al., 2002).

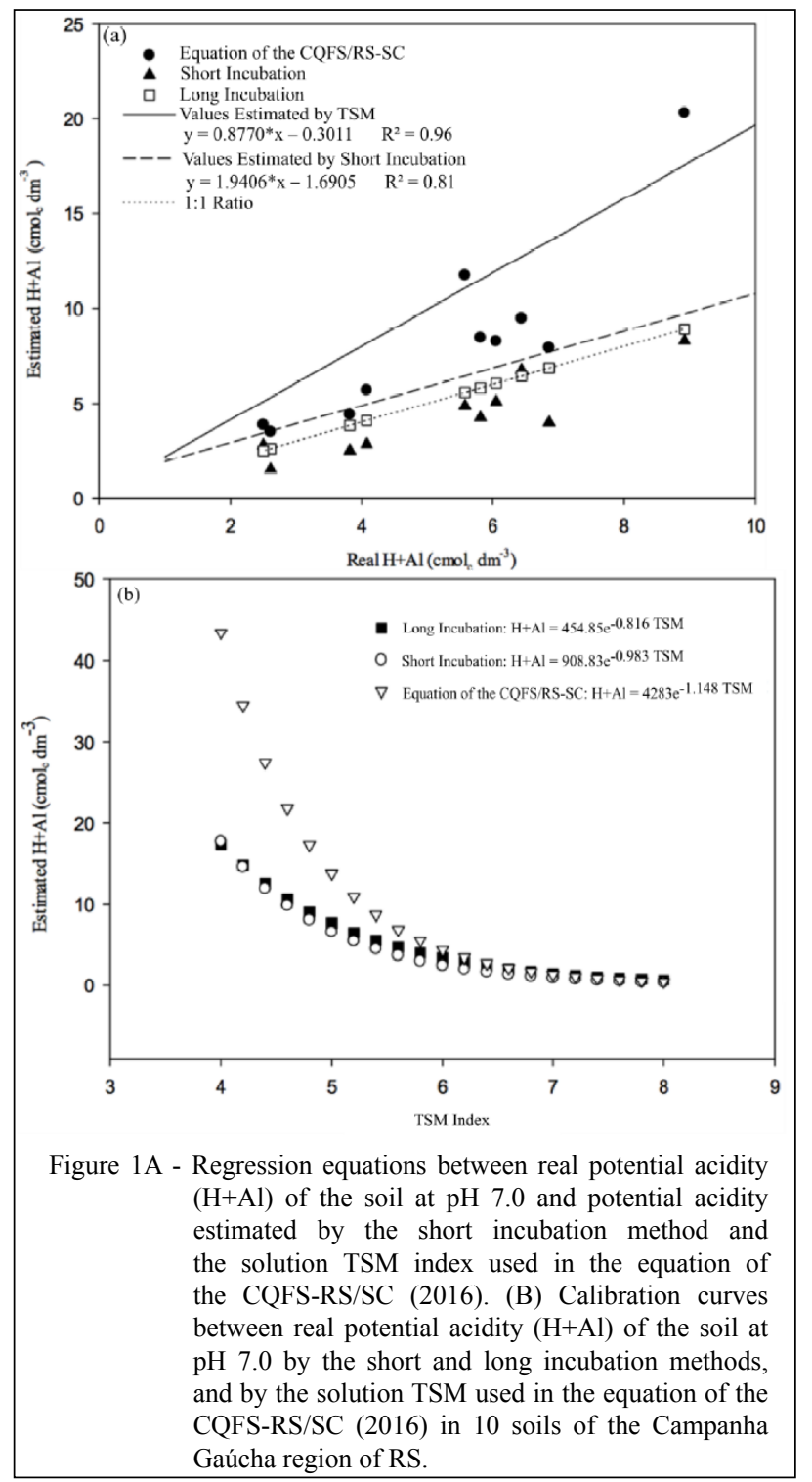

Ciência Rural, v.49, n.2, 2019. 
Conversely, the long and short incubation equations were similar to each other over a wide range of solution TSM $\mathrm{pH}$. This showed that incubation by both methods was equally efficient in correcting acidity, which corroborates with the results obtained by GIULIANI (2015). It should be noted that the values of $\mathrm{H}+\mathrm{Al}$ estimated by the long and short incubation equations at solution TSM $\mathrm{pH}$ values $<6.0$ were the same, even with the addition of solid $\mathrm{Ca}(\mathrm{OH})_{2}$ to complete the need to neutralize potential acidity (LIU et al., 2004; LIU et al., 2005), but with an incubation period of more than 48 hours, as advised by THOMPSON et al. (2010). These results are important as they differ from what was obtained by THOMPSON et al. (2010), who emphasized that soils submitted to long incubation overestimate the values of $\mathrm{H}+\mathrm{Al}$ in comparison to short incubation.
Conversely, at solution TSM $\mathrm{pH}$ higher than 6.0, the values of $\mathrm{H}+\mathrm{Al}$ estimated by the long and short incubation equations and obtained by the equation proposed by the CQFS-RS/SC (2016) were similar (Figure 1B). This is most likely due to the fact that soils with low potential acidity have low buffering, since they are typically soils with low organic matter and clay contents. For this reason, the estimation methods for these soils tend to be similar (LANA et al., 2013). Figure 1B clearly shows that for soils with a solution TSM pH lower than 6.0, the equations obtained by long or short incubation can be used to estimate $\mathrm{H}+\mathrm{Al}$ and; consequently, the lime dose. Lime doses estimated by short and long incubation below solution TSM pH 6.0 were lower than those estimated by the equation of the CQFS-RS/SC (2016) to raise the $\mathrm{pH}$ in water to 6.0 and 6.5 (Table 2). Conversely, at solution TSM

Table 2 - Estimation of the lime requirement to raise soil $\mathrm{pH}$ to 6.0 and 6.5 by long incubation, short incubation and by the solution TSM used in the equation of the CQFS-RS/SC (2016) in 10 soils of the Campanha Gaúcha region of RS.

\begin{tabular}{|c|c|c|c|c|c|c|}
\hline \multirow{3}{*}{ TSM } & \multicolumn{2}{|c|}{-------------Long Incubation-------------- } & \multicolumn{2}{|c|}{-----------Short Incubation------------ } & \multicolumn{2}{|c|}{---------Equation of the CQFS------- } \\
\hline & 6.0 & 6.5 & 6.0 & 6.5 & 6.0 & 6.5 \\
\hline & $\underset{\text { TSM }}{\mathrm{NL}}=87.051 \mathrm{e}^{-0.61}$ & 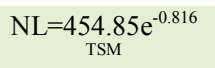 & $\underset{\text { TSM }}{\mathrm{NL}}=813.3 \mathrm{e}^{-1.42}$ & $\underset{T S M}{N L=}=\underset{ }{903.98} \mathrm{e}^{-0.983}$ & $\underset{T S M}{N L=7692 e^{-1.326}}$ & $\underset{\text { TSM }}{\mathrm{NL}}=\underset{2283 \mathrm{e}^{-1.148}}{4}$ \\
\hline \multicolumn{7}{|c|}{ 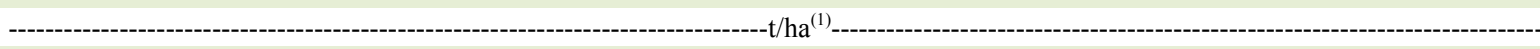 } \\
\hline 4.4 & 5.9 & 12.5 & 8.3 & 12.0 & 22.5 & 27.4 \\
\hline 4.5 & 5.6 & 11.6 & 7.5 & 10.8 & 19.7 & 24.4 \\
\hline 4.6 & 5.3 & 10.7 & 6.7 & 9.8 & 17.3 & 21.8 \\
\hline 4.7 & 5.0 & 9.8 & 6.1 & 8.9 & 15.1 & 19.4 \\
\hline 4.8 & 4.7 & 9.1 & 5.5 & 8.1 & 13.2 & 17.3 \\
\hline 4.9 & 4.4 & 8.3 & 4.9 & 7.3 & 11.6 & 15.4 \\
\hline 5.0 & 4.1 & 7.7 & 4.4 & 6.6 & 10.2 & 13.8 \\
\hline 5.1 & 3.9 & 7.1 & 4.0 & 6.0 & 8.9 & 12.3 \\
\hline 5.2 & 3.6 & 6.5 & 3.6 & 5.4 & 7.8 & 10.9 \\
\hline 5.3 & 3.4 & 6.0 & 3.2 & 4.9 & 6.8 & 9.8 \\
\hline 5.4 & 3.2 & 5.5 & 2.9 & 4.5 & 6.0 & 8.7 \\
\hline 5.5 & 3.0 & 5.1 & 2.6 & 4.1 & 5.2 & 7.8 \\
\hline 5.6 & 2.9 & 4.7 & 2.4 & 3.7 & 4.6 & 6.9 \\
\hline 5.7 & 2.7 & 4.3 & 2.1 & 3.3 & 4.0 & 6.2 \\
\hline 5.8 & 2.5 & 4.0 & 1.9 & 3.0 & 3.5 & 5.5 \\
\hline 5.9 & 2.4 & 3.7 & 1.7 & 2.7 & 3.1 & 4.9 \\
\hline 6.0 & 2.2 & 3.4 & 1.6 & 2.5 & 2.7 & 4.4 \\
\hline 6.1 & 2.1 & 3.1 & 1.4 & 2.2 & 2.4 & 3.9 \\
\hline 6.2 & 2.0 & 2.9 & 1.3 & 2.0 & 2.1 & 3.5 \\
\hline 6.3 & 1.9 & 2.7 & 1.1 & 1.8 & 1.8 & 3.1 \\
\hline 6.4 & 1.8 & 2.5 & 1.0 & 1.7 & 1.6 & 2.8 \\
\hline 6.5 & 1.7 & 2.3 & 0.9 & 1.5 & 1.4 & 2.5 \\
\hline 6.6 & 1.6 & 2.1 & 0.8 & 1.4 & 1.2 & 2.2 \\
\hline 6.7 & 1.5 & 1.9 & 0.8 & 1.2 & 1.1 & 2.0 \\
\hline 6.8 & 1.4 & 1.8 & 0.7 & 1.1 & 0.9 & 1.7 \\
\hline 6.9 & 1.3 & 1.6 & 0.6 & 1.0 & 0.8 & 1.6 \\
\hline 7.0 & 1.2 & 1.5 & 0.6 & 0.9 & 0.7 & 1.4 \\
\hline
\end{tabular}

${ }^{(1)}$ Limestone with Relative Total Neutralization Power (RTNP 100\%). NL=Need for limestone. 
$\mathrm{pH}$ higher than 6.0, the lime doses estimated by the three methods were similar.

The results showed that short incubation of the soil with $\mathrm{Ca}(\mathrm{OH})_{2}$ is a viable alternative to long incubation with $\mathrm{CaCO}_{3}$ to estimate $\mathrm{H}+\mathrm{Al}$ of soils with low organic matter and clay contents. Moreover, the estimation method of the equation proposed by the CQFS-RS/SC overestimated $\mathrm{H}+\mathrm{Al}$ and the lime doses when solution TSM pH values were lower than 6.0 for the soils evaluated in this study.

\section{DECLARATION OF CONFLICTING INTERESTS}

The authors declare no conflict of interest. The founding sponsors had no role in the design of the study; in the collection, analyses, or interpretation of data; in the writing of the manuscript, and in the decision to publish the results.

\section{ACKNOWLEDGEMENTS}

To the Conselho Nacional de Desenvolvimento Científico e Tecnológico (CNPq) for the productivity grants in research awarded to the first and last author. To the Coordenação de Aperfeiçoamento de Pessoal de Nível Superior (Capes) for grants awarded to Rogério Piccin and Lincon Stefanello authors. To the Fundação de Amparo à Pesquisa do Estado do Rio Grande do Sul (Fapergs) for the scholarship of scientific initiation granted to author Jacson Hindersmann.

\section{AUTHORS' CONTRIBUTIONS}

The graduation students Rodrigo Otávio Schneider Souza, Roque Junior Sartori Bellinaso, Rodrigo Krammes and Jacson Hindersmann were responsible for the collection of soil samples, incubations and laboratory analyzes. The postgraduate students Rogério Piccin and Lincon Stefanello were responsible for tabulation of the data, statistical analysis, confection of the figures, tables, and writing of the manuscript. Professors Gustavo Brunetto, João Kaminski, Carlos Alberto Ceretta and Luciano Colpo Gatiboni were responsible for planning the study, coordinating the activities, as well as writing and correcting the manuscript. All authors critically revised the manuscript and approved of the final version.

\section{REFERENCES}

COMISSÃO DE QUÍMICA E FERTILIDADE DO SOLO - CQFS - RS/SC. Manual de calagem e adubação para os Estados do Rio Grande do Sul e de Santa Catarina. 11.ed. Porto Alegre: SBCS - Núcleo Regional Sul/UFRGS, 376p, 2016.

FOX, R. H. Comparison of several lime requirement methods for agricultural soils in Pennsylvania. Communications in Soil Science and Plant Analysis, v.11, n.1, p.57-69, 1980. Available from: <https://doi.org/10.1080/00103628009367015>. Accessed: Aug. 17, 2017. doi: 10.1080/00103628009367015.

GAMA, M.A.P. et al. Potential acidity estimated by SMP $\mathrm{pH}$ in soils of the state of Pará. Revista Brasileira de Ciencia do Solo, 37:199-203, 2013. Available from: <http://dx.doi.org/10.1590/ S0100-06832013000100020>. Accessed: Sept. 05, 2017. doi: 10.1590/S0100-06832013000100020.

GIUliani, A. F. Determinação Da Acidez Potencial De Solos Pela Titulação Direta, 2015. 45 f. Dissertação (Mestrado) - Curso de Pós-Graduação em Ciência do Solo, Universidade Federal de Santa Maria.

KAMINSKI J. et al. Estimation of potential acidity in soils and their implication in calculating the need for limestone. Revista Brasileira De Ciência Do Solo, v.26, n.4, p.1107-1113, 2002. Available from: $\quad<$ http://dx.doi.org/10.1590/S0100-06832002000400029>. Accessed: Oct. 07, 2017. doi: 10.1590/S0100-06832002000400029.

LANA, R. M. Q. et al. Correlation of SMP and calcium acetate extractors in the determination of potential acidity in cerrado soil with different doses of limestone. Brazilian Geographical Journal: Geosciences and Humanities research medium, v.4, n.2, p.505614, 2013. Available from: <http://www.seer.ufu.br/index.php/ braziliangeojournal/article/view/23392>. Accessed: Oct. 07, 2017.

LIU, M. et al. Soil lime requirement by direct titration with calcium hydroxide. Soil Science Society of America Journal, Madison, v.68, p.1228-1233, 2004. Available from: https:// d1.sciencesocieties.org/publications/sssaj/abstracts/68/4/1228>. Accessed: Oct. 07, 2017. doi: 10.2136/sssaj2004.1228.

LIU, M. et al. Soil lime requirement by direct titration with Calcium Hydroxide. Soil Science Society Of America Journal, Madison, v.69, n.2, p.522-530, Mar. 2005. Available from: $<$ https:// dl.sciencesocieties.org/publications/sssaj/abstracts/69/2/0522>. Accessed: Dec. 11, 2017. doi: 10.2136/sssaj2005.0522.

SSALI, H.; NUWAMANYA, J. K. Soil acidity components of tropical acid soils: their roles in determining lime requirement values and the effect of lime upon them. Communications in Soil Science and Plant Analysis, v.13, n.3, p.203-214, 1982. Available from: < https://doi.org/10.1080/00103628209367260>. Accessed: Nov. 03, 2017. doi: 10.1080/00103628209367260.

TEDESCO, M.J. et al. Análise de solo, plantas e outros materiais, Porto Alegre: Departamento de Solos/UFRGS, 174p, 1995.

THOMPSON, J.; SCOTT, J. M. 'Environmental entrepreneurship: The sustainability challenge', Institute of small business and entrepreneurship conference (ISBE), London, November 2010. Available from: <http://hdl.handle.net/10149/120509>. Accessed: Nov. 15, 2017.

TOLEDO, J.A. et al. Santa Maria buffer (TSM) as an alternative to the SMP buffer for the measurement of the acidity potential of acid soils. Revista Brasileira de Ciencia do Solo, 36: 427 435, 2012. Available from: <http://dx.doi.org/10.1590/S010006832012000200012>. Accessed: Nov. 02, 2017. doi: 10.1590/ S0100-06832012000200012. 